ORIGINAL ARTICLE

\title{
Reproductive biology of Diopatra neapolitana (Annelida, Onuphidae), an exploited natural resource in Ria de Aveiro (Northwestern Portugal)
}

\author{
Adília Pires $^{1}$, Franck Gentil ${ }^{2}$, Victor Quintino ${ }^{1}$ \& Ana M. Rodrigues ${ }^{1}$ \\ 1 CESAM, Departmento de Biologia, Universidade de Aveiro, Aveiro, Portugal \\ 2 Station Biologique de Roscoff, Place Georges Teissier, Roscoff Cedex, France
}

\author{
Keywords \\ Larval development; life history; oocytes; \\ polychaeta; reproduction.

\section{Correspondence} \\ Ana Maria Rodrigues, CESAM, Departmento \\ de Biologia, Universidade de Aveiro, 3810- \\ 193 Aveiro, Portugal. \\ E-mail: anarod@ua.pt \\ Accepted: 14 May 2011
}

doi:10.1111/j.1439-0485.2011.00463.x

\begin{abstract}
Diopatra neapolitana Delle Chiaje, 1841 (Annelida, Onuphidae) is an important economic natural resource in Ria de Aveiro (northwestern coast of Portugal) and throughout Europe. The species is intensively harvested for use as fresh bait. However, there is only limited knowledge about its life cycle derived from a previous study in Mediterranean Sea. Reproduction and development patterns are known to vary biogeographically, making it important to base management decisions on locally appropriate information. This work examines reproduction patterns for populations from the Eastern Atlantic, which have not previously been assessed, with an eye towards drawing Atlantic-Mediterranean comparisons and informing local management strategies. The study was conducted from May 2007 to April 2009 in Ria de Aveiro. The reproductive biology of $D$. neapolitana was described from the proportional variation of worms with gametes in the coelom and from the progression of the oocyte diameter. Individuals with gametes inside the coelom were found all year round, but the peak reproductive period occurred between May and August, when almost all individuals had gametes in the coelom and females contained more oocytes than at any other time of the year. The overall male:female ratio was close to $1: 1$ and the oocyte diameter ranged from 40 to $240 \mu \mathrm{m}$. In vitro fertilization was performed and the results compared to other studies. Based on the present results, some protection measures are suggested to implement a sustainable exploitation of the species.
\end{abstract}

\section{Introduction}

The polychaete Diopatra neapolitana Delle Chiaje, 1841 (Onuphidae) inhabits intertidal mudflats and shallow subtidal transitional waters. The geographical distribution records indicate that it is a cosmopolitan species distributed throughout the Mediterranean (Gambi \& Giangrande 1986; Dagli et al. 2005), the Red Sea (Fauvel 1923) and the Eastern Atlantic (Fauvel 1923; Lourido et al. 2008) and Indian Oceans (Wehe \& Fiege 2002). However, in regions of the world where careful genetic and morphological analysis has been conducted, it was shown that D. neapolitana harbors multiple species. In
Europe, four species of Diopatra, D. neapolitana, Diopatra marocensis, Diopatra micrura and Diopatra sp. (not yet described) were identified and distinguished morphologically using characters that have not been used previously (Pires et al. 2010). Such analysis could be applied in other regions, in particular the Red Sea and Indian Ocean.

The species inhabits a tube, has a preference for sediments with mud or a mixture of mud and sand, and grows to about $60 \mathrm{~cm}$ (Fauvel 1923; Gambi et al. 1998; Dagli et al. 2005; Rodrigues et al. 2009). The tube consists of a secreted layer, to which sand particles, fragments of solid parts from other animals, such as shells, and algae attach to form a compact tube. 
Larval development in the Onuphidae is dependent on yolk reserves, with some species being lecithotrophic, feeding only after settlement, and others having a direct development (without larval stages) (Blake 1975; Giangrande 1997). Conti et al. (2005) report that D. neapolitana releases eggs and sperm into the water column and Bhaud \& Cazaux (1987) that it produces planktonic lecithotrophic larvae. Although the spawning of this species has never been observed in nature, artificial fertilization and culture of the larvae was reported by Bhaud \& Cazaux (1987) and Conti \& Massa (1998), who described several developmental phases. These authors showed that the larvae were lecithotrophic and free-swimming.

This species is collected to be sold as fish bait and this activity can be locally intense and economically important (Gambi et al. 1994; Conti \& Massa 1998). A previous study in Ria de Aveiro, Northwestern Portugal, where the present study was undertaken, indicated an annual harvest of $45,000 \mathrm{~kg}$, valued at over $€$ 325,000 (Cunha et al. 2005). According to Portuguese legislation, bait collection is only allowed by hand gathering or with restricted gear, such as a hoe, operated by licensed personnel (Portuguese legislation: Portaria no 144/2006 2006). No other legislation exists for the Ria de Aveiro and no management or conservation efforts are currently being developed for this species. Its reproductive biology is relatively unknown, as the only field work ever done on this subject was carried out in the Eastern Mediterranean Sea by Dagli et al. (2005).

The present study focuses on the gametes' characteristics, the larval development, the reproductive period, and the sex ratio of the population of $D$. neapolitana in Ria de Aveiro. Understanding these life history aspects is important for management and conservation efforts aimed at a sustainable exploitation of the species.

\section{Material and methods}

Study area and sampling

This study was conducted in Ria de Aveiro, Northwestern Portugal $\left(40^{\circ} 40^{\prime} 01.6^{\prime \prime} \mathrm{N}, 8^{\circ} 41^{\prime} 39.5^{\prime \prime} \mathrm{W}\right.$; Fig. 1). Ria de Aveiro is a shallow estuarine water system, receiving water from several rivers (Fig. 1), with the Vouga River accounting for more than $50 \%$ of the freshwater input, resulting in a complex system of bays, channels and extensive intertidal sand and mud flats (Dias et al. 1999).

Diopatra neapolitana specimens were collected intertidally, monthly from May 2007 to April 2009 with a shovel, at up to $30 \mathrm{~cm}$ depth. At least 50 specimens were collected randomly, each month, at the study area.

\section{Laboratory procedures}

In the laboratory worms were individually removed from their tubes and washed in sea water. Each specimen was partly dissected to search for the presence of gametes and then fixed in $70 \%$ ethanol. Fixed specimens were measured for width at the 10th chaetiger (without parapodia). Total length was measured in entire specimens (about 4\% of individuals). These morphological variables were only measured in individuals that were not seen to be regenerating.

The oocytes were extracted from females by dissection of the body cavity. The diameter of each oocyte was measured under a stereomicroscope (resolution 50×) using an ocular micrometer (precision of $0.01 \mathrm{~mm}$ ). The diameter of 100 oocytes was measured for each female. Different numbers of females were collected each month. During the periods with a larger number of mature individuals (April-August) oocytes were measured in at least 12 females. In the remaining study period, oocytes were measured in all the females collected, as their number was below 12. In some cases, only two to four females with oocytes in the coelom cavity were sampled. In total, oocytes from 332 females were measured. To count the total number of oocytes per female, only complete specimens were used - 12 in total. These were collected between May and December. During the study period, fresh sperm in sea water was observed under a microscope (resolution 1000×).

\section{Fertilization in vitro}

Specimens were collected from the study area and kept in the laboratory for at least 2 months. They were maintained at $22{ }^{\circ} \mathrm{C}$ and at a salinity range of 30-35. Salinity was measured with a hand-held refractometer and expressed using the practical salinity scale. To study larval development, artificial fertilization was performed following the method described by Conti \& Massa (1998) for Diopatra neapolitana. Females and males were cut laterally and left in separated dishes with sea water for 10-15 min to release the eggs and sperm. A portion of sperm was collected and added to the oocytes. The fertilized eggs were cultured at $22{ }^{\circ} \mathrm{C}$ and $30-35$ salinity. Sea water was changed daily.

The larval development observed in this study was analyzed following the descriptions of Bhaud \& Cazaux (1987) and Conti \& Massa (1998).

Once settled, the larvae were fed with homogenized cockles. Four days after fertilization, in the metatrocophore phase, the larvae were moved to an aquarium with fine sediment. The study of larval stages was carried out under an optical microscope. 


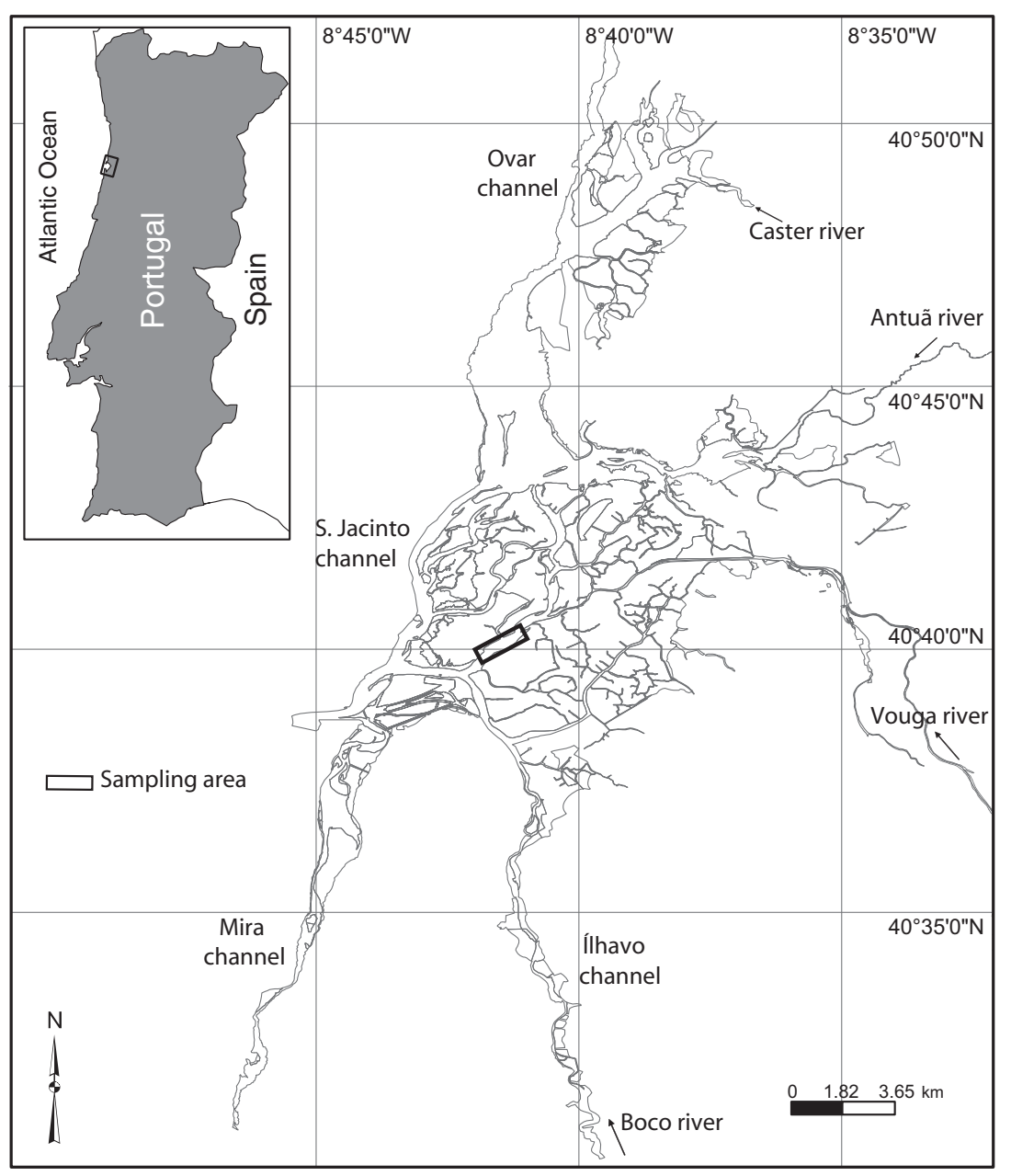

Fig. 1. General view of Ria de Aveiro, Portugal, showing sampling area.

\section{Data analysis}

The relationship between total length (L) and the width of the 10th chaetiger (W) was studied using second-order polynomial simple regression analysis. This relationship was established from 46 complete individuals, collected over the entire study period, according to the function $\mathrm{L}=\mathrm{a}+\mathrm{b}_{1} \mathrm{~W}+\mathrm{b}_{2} \mathrm{~W}^{2}$, forcing the model through the origin $(\mathrm{a}=0)$. SPSS software (version 17) was used to test the overall significance of the model (F-test) and of the second-order regression coefficient $\left(\mathrm{b}_{2}, t\right.$-test). The total expected body length of broken specimens was then determined from the measured width of the 10th chaetiger, using the regression function. This relationship was used to determine the expected shortest length of mature individuals.

The mean oocyte diameter (MOD) was calculated per female and per month, and its correlation with total length was assessed using the Pearson coefficient. The variance of oocyte diameter in the period of gametogenesis inactivity (November-January) was statistically compared
(F-test) with the period of gametes production (MarchOctober).

\section{Results}

Relationship between total length and width of the 10th chaetiger

Entire mature specimens ranged in size from 24 to $725 \mathrm{~mm}$, with the width of the 10th chaetiger varying between 1.9 and $10.88 \mathrm{~mm}$, respectively (Fig. 2). All observed specimens, entire or incomplete, had a 10th chaetiger width of between 1.9 and $13 \mathrm{~mm}$. The regression function relating the body length of the specimens (L, in $\mathrm{mm}$ ) to the width of the 10th chaetiger (W, in $\mathrm{mm})$ was statistically significant $(\mathrm{F}=1081.5$; $\mathrm{P}<0.0001$ ) and was given by the expression $\mathrm{L}=$ 17.955 W+4.209 $\mathrm{W}^{2}$. The regression coefficient associated with $\mathrm{W}^{2} \quad\left(\mathrm{~b}_{2}=4.209\right)$ was also found to be significantly different from zero, validating the secondorder polynomial $(\mathrm{t}=6.945 ; \mathrm{P}<0.0001)$. Under this 


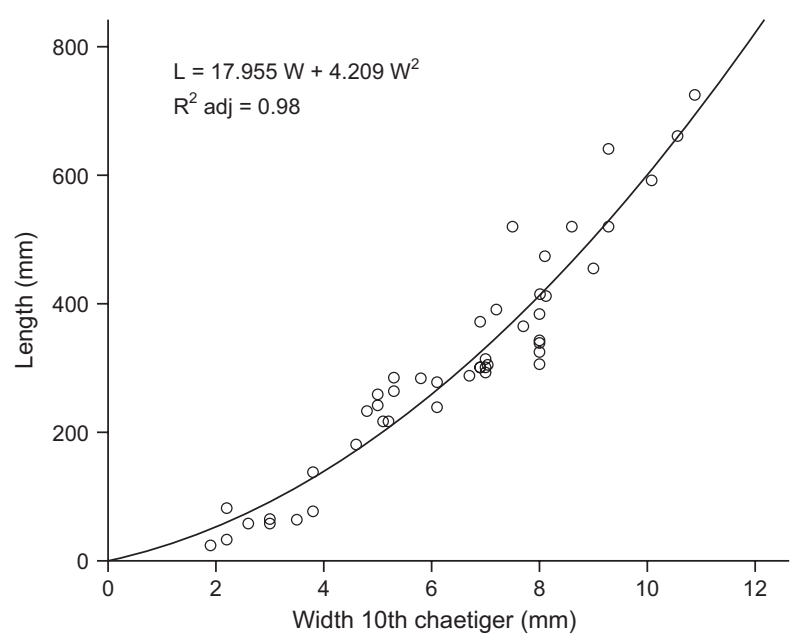

Fig. 2. Relationship between total length $(L)$ and width of the 10th chaetiger (W).

regression model, the width of the 10th chaetiger explained $98 \%$ of the total length variance $\left(R^{2}\right.$ adj $\left.=0.98\right)$. This regression function was used to estimate the total length of broken specimens. The smallest female observed to be carrying oocytes had $\mathrm{W}=4.2 \mathrm{~mm}$, corresponding to an estimated body length of $149.7 \mathrm{~mm}$. The smallest male with sperm in the coelom had $\mathrm{W}=4.0 \mathrm{~mm}$, corresponding to an expected body length of $139.2 \mathrm{~mm}$.

\section{Reproduction of Diopatra neapolitana}

The presence/absence of gametes was analyzed in 1163 specimens, of which 320 were males, 332 females and 511 undetermined (with no gametes in the coelom). No external morphological differences were noticed between males and females. However, during the main reproductive period males turned a cream color and females became greenish, mainly due to the gametes in the coelom.

The overall male:female sex ratio was close to 1:1 from April to September. For the other months, very few individuals with gametes were captured and the sex ratio was not determined.

The reproductive cycle of D. neapolitana can be inferred from the proportional variation of worms with gametes in the coelom, from the development of the size of oocytes and from the number of oocytes in complete females (Figs 3 and 4; Table 1). Individuals with gametes inside the coelom were always found, but the percentages of males, females and of individuals without gametes varied (Fig. 3) and showed a consistent pattern in the two consecutive years. In February 2008 and February 2009, a single specimen with oocytes and a single specimen with

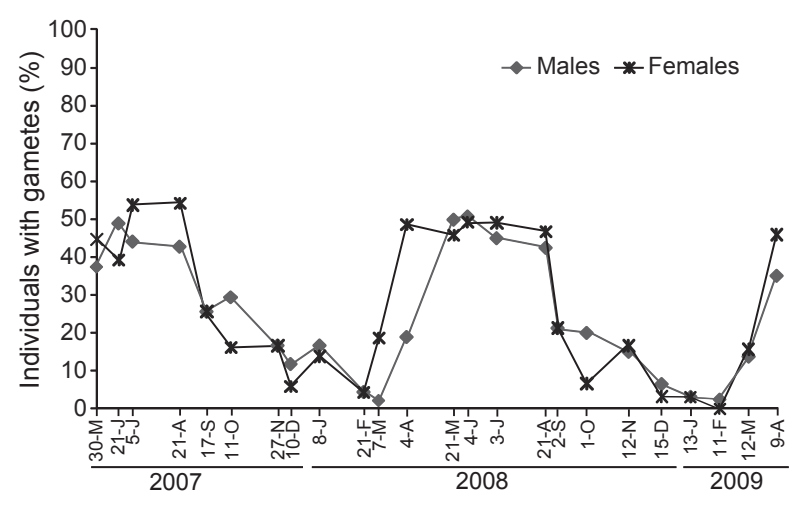

Fig. 3. Temporal development of males and females given as a percentage of the total number of specimens analyzed monthly. Only individuals with gametes were considered.

Table 1. Mean number of oocytes (with the standard deviation; SD) in complete females. The number of females analyzed in each month is shown in parentheses.

\begin{tabular}{lcr}
\hline months & No. oocytes & \multicolumn{1}{c}{ SD } \\
\hline May (2) & $1,821,846.5$ & $140,700.81$ \\
June (3) & $453,885.7$ & $90,239.58$ \\
August (3) & $73,131.5$ & 7252.79 \\
September (2) & $30,880.5$ & $11,716.05$ \\
October (1) & 20,190 & - \\
December (1) & 20,818 & - \\
\hline
\end{tabular}

sperm were found, respectively, whereas in April-August a larger proportion of individuals with gametes (varying from $39.22-54.29 \%$ in females and $35.14-50.0 \%$ in males) (Fig. 3) were found.

The smallest oocyte found in a female's coelom had a diameter of $40 \mu \mathrm{m}$ and the largest a diameter of $240 \mu \mathrm{m}$, with the mean for all specimens being $164.4 \pm 40.8 \mu \mathrm{m}$. Small oocytes $(<140 \mu \mathrm{m})$ were present in almost every month. The number of small oocytes reached a peak in March and April, decreasing until September. Oocytes were absent in some autumn/winter months (October, November and December) (Fig. 4). The decrease in the number of small oocytes paralleled the increase of larger oocytes (Fig. 4). The mean oocyte diameter was not correlated with the size of the females, measured by the width of the 10th chaetiger ( $\mathrm{r}=$ $-0.011 ; \mathrm{P}>0.05)$. Mean oocyte diameter increased rapidly from March to May, and continued to increase slowly until January (Fig. 4). The variance in oocyte size was significantly larger from March to October $\left(s^{2}=1354\right)$ than during the winter months, from November to January $\left(\mathrm{s}^{2}=264 ; \mathrm{F}=5.1 ; \quad \mathrm{P}<0.001\right)$. This can be appreciated in Figs 4 and 5 . 


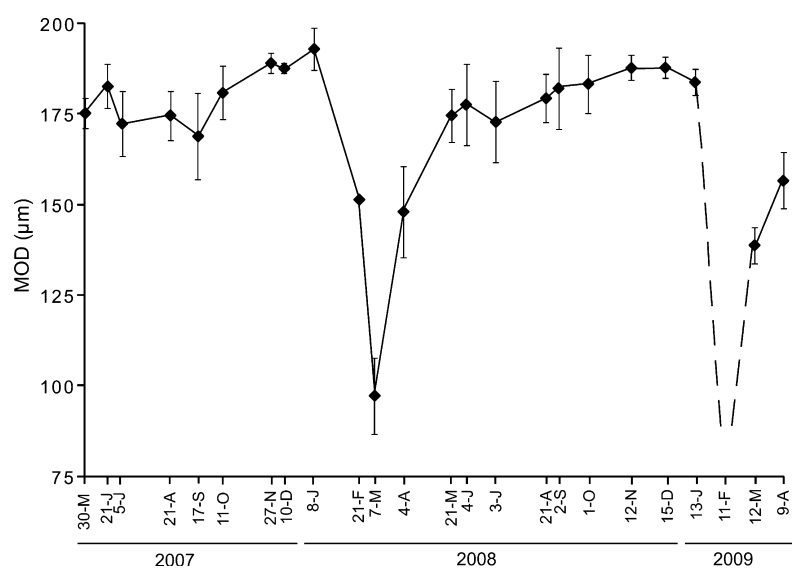

Fig. 4. Evolution of the mean oocyte diameter (MOD, $\mu \mathrm{m})$, during the study period. No specimens with oocytes in the coelom were obtained in February 2009. The bars represent the standard deviation.

Females from November to January contained mainly large oocytes of between 140 and $240 \mu \mathrm{m}$ (Fig. 5). Nurse cells were observed in oocytes with a diameter of up to $160 \mu \mathrm{m}$ (Fig. 6A). They were attached to the immature oocytes with two strings measuring up to $230 \mu \mathrm{m}$ in length $($ mean $=177.5 \pm 35.4 \mu \mathrm{m})$ and containing up to 39 cells (mean $29.4 \pm 4.5 \mu \mathrm{m}$ ) $12 \mu \mathrm{m}$ in diameter. Oocytes larger than $160 \mu \mathrm{m}$ did not have nurse cells attached (Fig. 6B).

Sperm had a spherical, short and rounded head with a long tail and were grouped in capsules in the coelom. When sperm were observed under the microscope, between May and August, the majority of the males contained spermatozoa with a mobile flagellum, moving actively in sea water. From October to January, spermatozoa had tails but reduced mobility. Sperm were immobile during the other months.

The first chaetiger with gametes varied. In females where the oocytes were observed they were located between the 35th and the 70th chaetiger. In males, sperm were found from chaetigers 50 to 70 . The mean location of the chaetiger where gametes first appeared was $52.7 \pm 8.6$ for oocytes and $59.3 \pm 7.3$ for sperm. No significant correlation was found between the first chaetiger bearing gametes and the size of the individuals $(r=0.01)$.

In May and June, the months where it was possible to count the total number of oocytes per female (complete females), females had the highest number of oocytes in the coelom (Table 1).

\section{Fertilization in vitro}

Table 2 presents the main characteristics of larval development of Diopatra neapolitana in this and in other studies (Bhaud \& Cazaux 1987; Conti \& Massa 1998).
Larval development was followed up to the age of 7 days. Seven hours after fertilization the embryo had cilia and swam in the water column, becoming a freeswimming protrochophore larva after $19 \mathrm{~h}$. The protrochophore larvae were sub-spherical, with an apical tuft and were almost completely covered by cilia $210 \mu \mathrm{m}$ in length. At 2-3 days after fertilization, the metatrocophore larvae had a length of between 240 and $280 \mu \mathrm{m}$ and were segmented in three chaetigers with chaetae; the prostomium was ciliated and with two red eyes. After 3 days, the metatrocophore larvae lost the apical tuft, had four chaetigers and a length of $300 \mu \mathrm{m}$. On the 4 th day, some metatrocophore larvae swam slowly in the water column, and others started to sink to the bottom and aggregate detritus around them. At this phase, larvae were moved to an aquarium with fine sediment and fresh sea water to allow the larvae to create a wrapping and protecting niche, and later permit the construction of the tube.

Juveniles were observed 7 days after fertilization and had five chaetigers, five small antennae on the prostomium, and a pair of small anal cirri in the pygidium. Tube formation was not observed, although individuals with particles around the body were seen.

\section{Regenerating specimens}

During the study period, about $5 \%$ of the specimens were regenerating the anterior end of the body, from two to 13 chaetigers. A minor proportion of specimens, about $0.3 \%$, were regenerating the posterior end and a much larger number of chaetigers $(56$ to $>100$ ). Specimens regenerating the anterior end were found in almost all the sampling occasions, and represented between 1.4\% and 17.0\% of the sampled population. Individuals regenerating the posterior end were rare and only observed in 5 sampling occasions, randomly scattered throughout the sampling period. The majority of the regenerating specimens did not contain gametes, with the exception of some females with small oocytes.

\section{Discussion}

The study of the reproductive biology of Diopatra neapolitana showed that this species contained gametes in the coelom in all months of the year, but had the highest proportion of individuals with gametes from May to August. These results are similar to those of Dagli et al. (2005) in Izmir Bay, Turkey, where individuals with gametes were reported all year round, except in January. The number of oocytes in the females' body cavity was higher in May-August, but was decreasing during this period. In the month of October and December, it was similar numbers of oocytes were found in the body cavity 

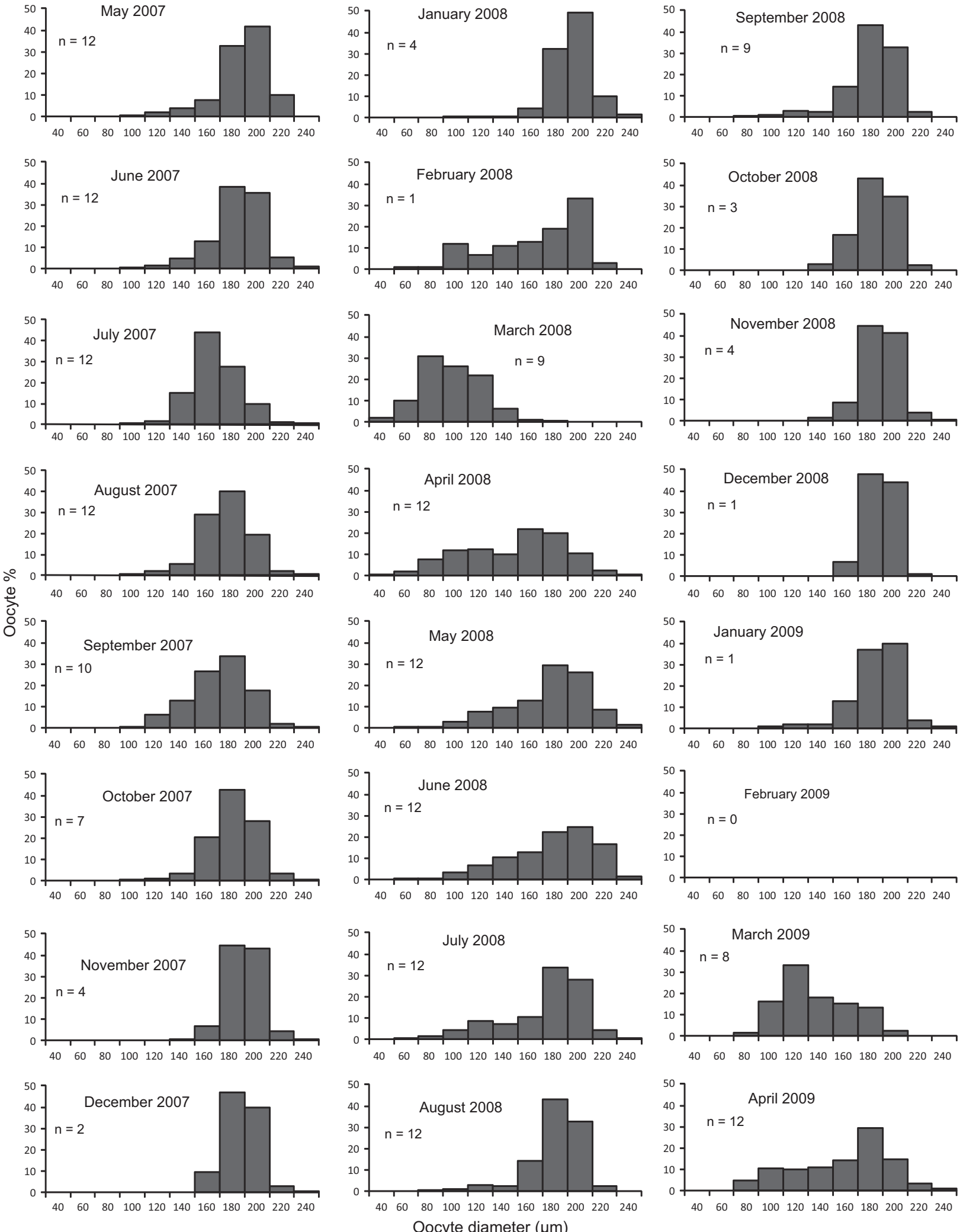

Fig. 5. Size-frequency distribution of oocytes of Diopatra neapolitana during the study period ( $\mathrm{n}=$ number of females observed). 

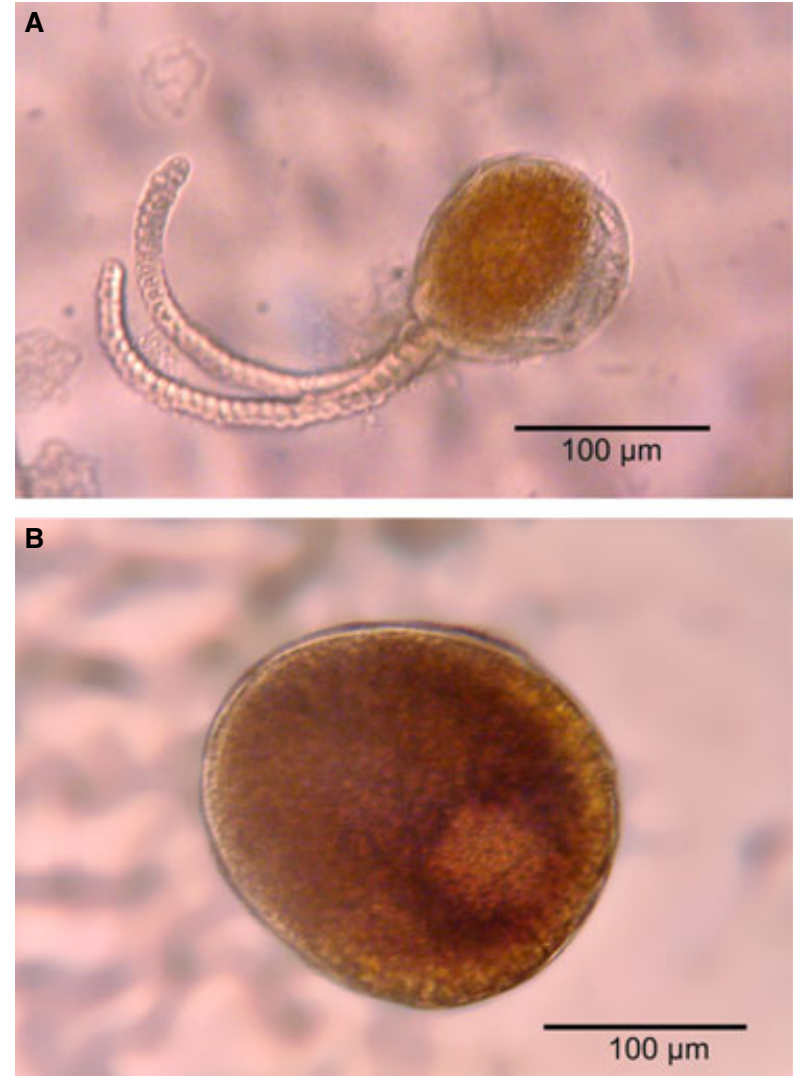

Fig. 6. Oocytes of Diopatra neapolitana. (A) Immature oocyte with nurse cells attached. (B) Mature oocyte. of females, suggesting that no oocytes were released over this period. A number of small oocytes $(<140 \mu \mathrm{m})$ was present almost every month, showing a peak in March and April, and then decreasing until September. The absence of small oocytes between November and January indicates that the females were not producing oocytes. The large oocytes probably were not expelled during spawning and remained in the coelom cavity. The decrease of small oocytes was paralleled by an increase in the number of larger oocytes.

Conti et al. (2005) described mature sperm of $D$. neapolitana as having a long tail attached to a spherical, short and rounded head, which is similar to our findings for sperm from May to August. The sperm also had the highest mobility during this period. These results indicate that the beginning of gametogenesis should be in March/April, the spawning period from May to August, and gametogenic inactivity from November to February.

The oocyte diameter varied between 40 and $240 \mu \mathrm{m}$, with a mean of $164.4 \pm 40.8 \mu \mathrm{m}$. Oocytes should be released from the coelom into the water column with a diameter of about $200 \mu \mathrm{m}$ (Dagli et al. 2005). In fact, in the present study only a small percentage of the oocytes remaining in the coelom had a larger diameter. This is in agreement with our observations of the artificial fertilization, and with Bhaud \& Cazaux's (1987) results, as the fertilized eggs had a diameter between 210 and $215 \mu \mathrm{m}$.

Table 2. Principal characteristics of larval development of Diopatra neapolitana in this study and in comparison with Bhaud \& Cazaux (1987) and Conti \& Massa (1998).

\begin{tabular}{|c|c|c|c|}
\hline & present study & Bhaud \& Cazaux (1987) & Conti \& Massa (1998) \\
\hline$P$ & $\begin{array}{l}19 \text { h. Shape sub-spherical. Almost } \\
\text { completely covered by cilia. Apical tuft. } \\
\text { Larvae swimming actively in water column }\end{array}$ & $\begin{array}{l}24 \text { h. Shape sub-spherical to piriform. } \\
\text { Length } 215 \mu \mathrm{m} \text {. Almost completely } \\
\text { covered by cilia. Apical tuft. Larvae } \\
\text { swimming in water column }\end{array}$ & $5 \mathrm{~h}$. Larvae swim free in the water column \\
\hline M & $\begin{array}{l}\text { 2-3 days. Length } 240-280 \mu \mathrm{m} .3 \\
\text { chaetigers. Prostomium ciliated. } 2 \text { red eyes }\end{array}$ & $\begin{array}{l}3 \text { days. Length } 240 \mu \mathrm{m} .3 \text { chaetigers. } \\
\text { Prostomium ciliated. } 2 \text { red eyes }\end{array}$ & $24 \mathrm{~h}$. Larvae present. Positive phototropism \\
\hline M & $\begin{array}{l}3 \text { days. Length } 300 \mu \mathrm{m} .4 \text { chaetigers. Loss } \\
\text { of apical tuft. } 2 \text { red eyes. } \\
4 \text { days. } 380 \mu \mathrm{m} .4 \text { chaetigers. } 2 \text { red eyes. } \\
\text { Some of them swimming in water column } \\
\text { and others on the bottom, with detritus } \\
\text { around them (starting the tube construction) }\end{array}$ & $\begin{array}{l}4 \text { days. Length } 390 \mu \mathrm{m} \text {. } 4 \text { chaetigers. Loss } \\
\text { of apical tuft. } 2 \text { red eyes. } \\
\text { 4-5 days. Larvae sink to the bottom and } \\
\text { produce mucus where particles will } \\
\text { aggregate }\end{array}$ & $\begin{array}{l}3 \text { days. Larvae sink to the bottom. } 4 \text { days. } \\
\text { Black jaws visible through body cavity. } 3 \\
\text { chaetigers. Larvae start to agglutinate } \\
\text { diverse detritus }\end{array}$ \\
\hline$E$ & $\begin{array}{l}\text { 5-6 days. } 500 \mu \mathrm{m} .5 \text { chaetigers, } 2 \text { red eyes. } \\
5 \text { large buds in prostomium. Rudimentary } \\
\text { anal cirri. Black jaws visible through body } \\
\text { cavity }\end{array}$ & $\begin{array}{l}6 \text { days. Length } 550 \mu \mathrm{m} .5 \text { chaetigers. } 5 \\
\text { large round antennal buds at the front of } \\
\text { the prostomium. Black jaws visible through } \\
\text { body cavity, rudimentary anal cirri }\end{array}$ & Not described \\
\hline J & $\begin{array}{l}7 \text { days. Length } 540 \mu \mathrm{m} .5 \text { chaetigers. } 2 \text { red } \\
\text { eyes. } 5 \text { small antennae on the } \\
\text { prostomium. } 2 \text { anal cirri. Juvenile present } \\
\text { positive phototropism }\end{array}$ & $\begin{array}{l}7 \text { days. Parapodia more developed. } 5 \\
\text { antennae. } \\
16 \text { days. Length } 1250 \mu \mathrm{m} .7 \text { chaetigers. } \\
\text { Parapodia and antennae more developed }\end{array}$ & $\begin{array}{l}1 \text { month. } 25 \text { chaetigers. First branchia } \\
\text { appears in } 5 \text { th parapodia. } \\
1 \text { month and } 20 \text { days. Second branchia } \\
\text { appears in } 6 \text { th parapodia. } \\
3 \text { months. Length } 15 \mathrm{~mm}\end{array}$ \\
\hline
\end{tabular}

P, protrocophore; M, metatrocophore; E, erpochaeta; J, juvenile. 
Nurse cells were observed in oocytes with a diameter equal or less to $160 \mu \mathrm{m}$, as reported by Dagli et al. (2005) and reached up to 39 cells, $230 \mu \mathrm{m}$ long, and $12 \mu \mathrm{m}$ wide, which is larger than observed by Dagli et al. (2005). Nurse cells are common in the Onuphidae family, and they probably transport nutrients taken up from the coelomic fluid to the developing oocytes. Usually, larger oocytes had few or no nurse cells attached, probably because nutrients will not be absorbed by the mature oocytes (Blake 1975).

During the study period, some individuals were regenerating the anterior end of the body. The regenerative capacity of the anterior segments has already been observed for Diopatra species, including D. neapolitana (Beli 2006). The majority of individuals that were regenerating the anterior end had no gametes in the coelom, except for some females that contained small oocytes. It is thus possible that the individuals in regeneration concentrate all their energy on this process.

The first chaetiger with gametes ranged in females from the 35 th to the 70 th and in males from the 50th to 70th, usually after the chaetigers with branchiae. These results are very similar to those obtained by Dagli et al. (2005), who reported the appearance of oocytes in chaetiger $55 \pm 0.9$ (mean) and of sperm in chaetiger $51 \pm 0.9$ (mean). In agreement with those authors, our study confirmed the absence of a significant correlation between the first appearance of the oocytes and the width of the 10th chaetiger, chosen as a measure of the total length of the specimens.

In the present study, the smallest mature male and female were 139.2 and $149.7 \mathrm{~mm}$ long, respectively. These values are higher than those obtained by Dagli et al. (2005), who reported minimum length in females of 125 and in males of $110 \mathrm{~mm}$. However, in their study, the largest entire worm had a length of $347 \mathrm{~mm}$, whereas in our study we found larger individuals. During our collecting period we harvested 46 complete individuals with a total length between $24 \mathrm{~mm}$ and $725 \mathrm{~mm}$. Only specimens of about $600 \mathrm{~mm}$ long are reported in the literature.

According to Paxton (1993), there are four reproduction patterns in Diopatra: Group I - species that breed in the parental tube, Group II - species with direct development in a cocoon, Group III - species that attach their eggs to the parental tube and present direct development, and Group IV - species with broadcast spawning with a free-swimming larval stage. Diopatra neapolitana belongs to group IV, as no eggs were observed inside the tubes or any gelatinous mass containing eggs attached to their distal end. This conclusion is supported by the artificial fertilization experiment, where only free-swimming lecithotrophic larvae were observed. This is also in agreement with the conclusions of Dagli et al. (2005). In our fertilization experiment, free-swimming protrocophore larvae were obtained $19 \mathrm{~h}$ after fertilization, at $22^{\circ} \mathrm{C}$. In Conti \& Massa (1998), this phase appeared $5 \mathrm{~h}$ after fertilization $\left(25-32{ }^{\circ} \mathrm{C}\right)$ and Bhaud \& Cazaux (1987) only observed the protrochophore larva $24 \mathrm{~h}$ after fertilization. The larvae developed faster in Conti \& Massa's (1998) study compared with our study and Bhaud \& Cazaux's (1987) description. Morphologically, the results of our experiment were similar to Bhaud \& Cazaux's (1987) larval description, but the time of development was different, as in our study, larvae developed faster (about 1 day) until the metatrocophore phase.

These differences could be explained by the temperature, $22{ }^{\circ} \mathrm{C}$ in our case, and $25-32{ }^{\circ} \mathrm{C}$ in Conti \& Massa (1998); temperature was never mentioned in Bhaud \& Cazaux (1987). The number of larvae or the size of the containers could influence larval development, but we do not have information about these features. Larvae of D. neapolitana observed in our experiments and in Bhaud \& Cazaux (1987) were morphologically different to those described by Choe (1960) in Japan as being D. neapolitana. This supports Paxton's (1993) suggestion that the species mentioned by Choe (1960) was not D. neapolitana (Paxton 1993).

Larval development has also been studied in other Diopatra species, namely Diopatra cuprea (Allen 1959), which has a developmental pattern similar to D. neapolitana, and Diopatra marocensis (Fadlaoui et al. 1995), which breeds in the parental tube. The first larval stage observed in this study in D. neapolitana, the protrochophore, was similar to that described for D. cuprea (Allen 1959) and D. marocensis (Fadlaoui et al. 1995). This stage is characterized in the three species by the presence of the apical tuft and ciliation around the body. Diopatra neapolitana and D. cuprea are active swimmers and had red eye spots during the initial development stages. Diopatra cuprea starts to settle to the bottom 3 days after fertilization, with four chaetigers, producing mucus to build the tube (Allen 1959). This was similar to what was observed in this study for D. neapolitana. Five antennae and anal cirri were observed at the 5 th-chaetiger stage in D. cuprea and D. neapolitana, and at the 6th-chaetiger stage for D. marocensis. In D. marocensis, the ceratophores appear at the 12th-chaetiger stage and in D. cuprea at the 5thchaetiger, with one to two rings, whereas in D. neapolitana the ceratophores still had no rings at the 50th-chaetiger stage (Conti \& Massa 1998). According to these authors, the first branchiae appear at the 25th-chaetiger stage on the 5 th chaetiger in D. neapolitana, and at the 18-20th chaetiger stage in D. marocensis, also on the 5th chaetiger (Fadlaoui et al. 1995).

In Ria de Aveiro, D. neapolitana is intensively exploited as live fish bait. No management or conservation regulations are currently set for the species and there is very 
little legislation. In the case of the Sado estuary, located about $350 \mathrm{~km}$ south of Ria de Aveiro, harvesting of D. neapolitana, Marphysa sanguinea and Hediste diversicolor is not allowed from 1 November until 30 April (Portuguese legislation: Portaria no 576/2006 2006). That period is reported in the legislation as coinciding with spawning and juvenile growth. However, this is not supported by the present or other studies. The main reproductive period for $H$. diversicolor in the Sado estuary was from April to August/September (Garcês, unpublished data). In the Southwestern coast of Portugal (Odeceixe, Aljezur and Carrapateira) the same species was reported as reproducing throughout the year, with important peaks in September and May (Fidalgo e Costa 2003). In Ria de Aveiro, the species also showed two important reproductive periods, in March and September (Abrantes et al. 1999). The reproductive period of Marphysa sanguinea was mainly from March/April to October/November in the Sado estuary (Garcês, unpublished data) and a peak spawning period in April-May was reported from the Venice Lagoon (Italy) by Prevedelli et al. (2007). The main reproduction peak for $D$. neapolitana in the present study and in that of Dagli et al. (2005), in Izmir Bay (Eastern Mediterranean), was from May to August.

In Portugal, with the exception of the resting period established for the Sado estuary, the exploitation of polychaetes occurs all year, being more intense in warm months. Cancela da Fonseca \& Fidalgo e Costa (2008) observed that the capture of these species has increased in recent years and that the mean size of harvested individuals is smaller. Dagli et al. (2005) reported that D. neapolitana occurred in the past in high densities in Inciralti (Mediterranean Sea), and by the time they did their study, the species was only present in their study area. They also observed that each digger needed $10 \mathrm{~h}$ to collect about 2000 specimens, whereas 10 years before they collected the same number in only $2 \mathrm{~h}$.

The digging activity has negative impacts on the entire ecosystem. The benthic community is affected as a whole, as are the species which depend on it for food (mainly birds and fishes). In addition, the biogeochemical cycles could be affected and the release of nutrients and bio-availability of metals enhanced (Cancela da Fonseca \& Fidalgo e Costa 2008). All of this emphasizes the urgent need for a sustainable exploitation of these natural resources, not only in Ria de Aveiro but in all coastal areas. The use of scientifically supported legislation coupled with control in the allocation of bait-digging licenses with regular monitoring of the impacted areas should be implemented. Mitigation measures could be applied either by restricting the harvest (in the case of D. neapolitana in Ria de Aveiro, the most suitable period seems to be April until Septem- ber) or by establishing yearly rotating resting areas. The rotation system has been suggested as an effective solution to minimize the negative impacts of this kind of resource exploitation by Fowler (1999) and Cancela da Fonseca \& Fidalgo e Costa (2008) and is being used in Korea, which is one of the largest exporters of bait polychaetes in the world (Choi 1985).

\section{Acknowledgements}

Adília Pires benefited from a $\mathrm{PhD}$ grant (SFRH/BD/ 28509/2006) from the Portuguese FCT (Fundação para a Ciência e Tecnologia). Aldiro Pereira assisted the sampling campaigns. Donald McLusky was kind enough to review the English. Three anonymous referees made very fruitful comments.

\section{References}

Abrantes A., Pinto F., Moreira M.H. (1999) Ecology of the polychaete Nereis diversicolor in the Canal de Mira (Ria de Aveiro, Portugal): Population dynamics, production and oogenic cycle. Acta Oecologica, 20, 267-283.

Allen M.J. (1959) Embryological development of the polychaetous annelid, Diopatra cuprea (Bosc). The Biological Bulletin, 116, 339-361.

Beli A.E. (2006) Distribution of segment regeneration ability in the Annelida. Integrative and Comparative Biology, 46, 508-518.

Bhaud M., Cazaux C. (1987) Description and identification of polychaete larvae: their implication in current biological problems. Oceanis, 13: 596-753.

Blake J.A. (1975) The larval development of Polychaeta from the northern California Coast. II. Nothria elegans (family Onuphidae). Ophelia, 13, 43-61.

Cancela da Fonseca L., Fidalgo e Costa P. (2008) Poliquetas: sua obtenção, impactos e medidas de gestão. 14 Congresso Anual da APDR e 20 Congresso de Gestão e Conservação da Natureza 'Desenvolvimento, Administração e Governança Local', Tomar, 4 e 5 Julho. In: Acta Ambiente e Conservação da Natureza, 833-851.

Choe S. (1960) On the life history of the Polychaete worm Diopatra neapolitana, Delle Chiaje. Bulletin of the Japanese Society of Scientific Fisheries, 26, 430-437.

Choi I.H. (1985) Lugworms: from harvesting to exporting. Infofish Marketing Digest, 6, 49-52.

Conti G., Massa F. (1998) Experienze de allavamento del polichete Diopatra neapolitana Delle Chiaje, 1841 nella Laguna di S. Gilla (Sardegna Meridionale). Biologia Marina Meditteranea, 5, 1473-1480.

Conti G., Loffredo F., Lantini M.S. (2005) Fine structure of the spermatozoon of Diopatra neapolitana (Polychaeta, Onuphidae). Zoomorphology, 124, 155-160. 
Cunha T., Hall A., Queiroga H. (2005) Estimation of the Diopatra neapolitana annual harvest resulting from digging activity in Canal de Mira, Ria de Aveiro. Fisheries Research, 76, 56-66.

Dagli E., Ergen Z., Çinar M.E. (2005) One-year observation on the population structure of Diopatra neapolitana Delle Chiaje (Polychaeta, Onuphidae) in Izmir Bay (Aegean Sea, eastern Mediterranean). Marine Ecology, 26, 265-272.

Dias J.M., Lopes J.F., Dekeyser I. (1999) Hydrological characterization of Ria de Aveiro, Portugal, in early summer. Oceanologica Acta, 22, 473-485.

Fadlaoui S., Lechapt J.-P., Retiere C. (1995) Larval development of the onuphid Diopatra marocensis (Annelida: Polychaeta) from the Atlantic coast of Morocco. Journal of the Marine Biological Association of the United Kingdom, 75, 957-966.

Fauvel P. (1923) Polychétes Sedentaires, Vol. 5. Faune de France V. le Chevalier, Paris: 1-488.

Fidalgo e Costa P. (2003) The oogenic cycle of Nereis diversicolor (O.F Muller, 1776) (Annelida: Polychaeta) in shallow waters environments in southwestern Portugal. Boletin del Instituto Espanol de Oceanografia, 19, 17-29.

Fowler S.L. (1999) Guidelines for managing the collection of bait and other shoreline animals within UK European marine sites. English Nature (UK Marine SACs Project), The Nature Conservation Bureau Ltd., 132 pp.

Gambi M.C., Giangrande A. (1986) Distribution of softbottom Polychaetes in two coastal areas of the Tyrrhenian Sea (Italy): structural analysis. Estuarine, Coastal and Shelf Science, 23, 847-862.

Gambi M.C., Castelli A., Giangrande A., Lanera P., Prevedelli D., Zunarelli-Vandini R. (1994) Polychaetes of commercial and applied interest in Italy: an overview. In: Dauvin J.C., Laubier L., Reish D. (Eds) Actes de la 4eme Conference internationale des Polychetes. Memoires du Museum National d'Histoire Naturelle de Paris, 162, 593-601.
Gambi M.C., Conti G., Bremec S.C. (1998) Polychaete distribution, diversity and seasonality related to sea grass cover in shallow soft bottoms of Tyrrhenian Sea (Italy). Scientia Marina, 62, 1-17.

Giangrande A. (1997) Polychaete reproductive patterns, life cycle and life histories: an overview. Oceanography and Marine Biology. An Annual Review, 35, 323-386.

Lourido A., Cacabelos E., Troncoso J.S. (2008) Patterns of distribution of the polychaete fauna in subtidal soft sediments of the Ría de Alda'n (north-western Spain). Journal of the Marine Biological Association of the United Kingdom, 88, 263-275.

Paxton H. (1993) Diopatra Audouin and Milne Edwards (Polychaeta: Onuphidae) from Australia, with a discussion of development patterns in the genus. Beagle, 10, 115-154.

Pires A., Paxton H., Quintino V., Rodrigues A.M. (2010) Diopatra (Annelida: Onuphidae) diversity in European waters with the description of Diopatra micrura, new species. Zootaxa, 2395, 17-33.

Portaria no 144/2006 (2006) Alteração ao Regulamento da Apanha, aprovado pela Portaria no 1102-B/2000, de 22 de Novembro. Diário da República, 20/02/2006, série I-B, no 36. 1300-1305.

Portaria no 576/2006 (2006) Diário da República, 19/06/2006, série I-B, no 116. 4336.

Prevedelli D., Mossamba N'Siala G., Ansaloni I., Simonini R. (2007) Life cycle of Marphysa sanguinea (Polychaeta: Eunicidae) in the Venice Lagoon (Italy). Marine Ecology, 28, 1-10.

Rodrigues A.M., Pires A., Mendo S., Quintino V. (2009) Diopatra neapolitana and D. marocensis from the Portuguese coast: morphological and genetic comparison. Estuarine, Coastal and Shelf Science, 85, 609-617.

Wehe T., Fiege D. (2002) Annotated checklist of the polychaete species of the seas surrounding the Arabian Peninsula: Red Sea, Gulf of Aden, Arabian Sea, Gulf of Oman, Arabian Gulf. Fauna of Arabia, 19, 7-238. 